Review

\title{
Implementation of Whole School Restorative Approaches to Promote Positive Youth Development: Review of Relevant Literature and Practice Guidelines
}

\author{
Laia Mas-Expósito ${ }^{1, *}$, Virginia Krieger ${ }^{2}$, Juan Antonio Amador-Campos ${ }^{2,3}$ (D), Rocío Casañas ${ }^{1}$ (D), Mònica Albertí 4 \\ and Lluís Lalucat-Jo ${ }^{1}$
}

check for

updates

Citation: Mas-Expósito, L.; Krieger, V.; Amador-Campos, J.A.; Casañas,

R.; Albertí, M.; Lalucat-Jo, L. Implementation of Whole School Restorative Approaches to Promote Positive Youth Development: Review of Relevant Literature and Practice Guidelines. Educ. Sci. 2022, 12, 187. https://doi.org/10.3390/ educsci12030187

Academic Editor: James Albright

Received: 17 January 2022

Accepted: 3 March 2022

Published: 7 March 2022

Publisher's Note: MDPI stays neutral with regard to jurisdictional claims in published maps and institutional affiliations.

Copyright: (C) 2022 by the authors. Licensee MDPI, Basel, Switzerland. This article is an open access article distributed under the terms and conditions of the Creative Commons Attribution (CC BY) license (https:// creativecommons.org/licenses/by/ $4.0 /)$
1 Research Department, Associació Centre d'Higiene Mental Les Corts, 08029 Barcelona, Spain; rocio.casanas@chmcorts.com (R.C.); lluis.lalucat@chmcorts.com (L.L.-J.)

2 Department of Clinical Psychology and Psychobiology, Faculty of Psychology, University of Barcelona, 08035 Barcelona, Spain; v.krieger@ub.edu (V.K.); jamador@ub.edu (J.A.A.-C.)

3 Institute of Neuroscience-Ubneuro, University of Barcelona, 08035 Barcelona, Spain

4 Research Group in Education, Society and Innovation with the Support of Information and Communication Technologies-PSITIC, Blanquerna-Universitat Ramon Llull, 08022 Barcelona, Spain; monicaalbertic@gmail.com

* Correspondence: laia.mas@chmcorts.com

\begin{abstract}
Positive youth development highlights the promotion of skills through engaging and caring settings and building opportunities for bidirectional and constructive relationships. Whole School Restorative Approaches (WSRA) promote school community relationships and social and emotional skills which are core components for positive youth development. To our knowledge, the literature reviews on the implementation of restorative practice approaches in schools do not focus specifically on WSRA and are not comprehensive. This study carries out a systematic review of the empirical evidence on the effectiveness of WSRA and develops some evidence-based practice guidelines on their effects. Thirteen studies met the inclusion criteria and we developed 10 evidence-based practice guidelines on the implementation of WSRA. There were many studies with WSRA showing positive results related to improving social and emotional skills and behavior. The highest level of scientific evidence is for secondary education where two WSRA are recommended. Although our review suggests that more rigorous methodological research is necessary, it also points out that the evidence available on WSRA implementation is encouraging. They could be used through all educational stages to deal with diversity and inclusion while promoting a school culture of peace based on the positive management of relationships and conflicts.
\end{abstract}

Keywords: restorative approach; school; relationships; psychosocial development; guidelines

\section{Introduction}

The plasticity of individual development comes from the integration of contextual and biological systems [1]. One could take part in plasticity of developmental trajectories by promoting bidirectional and positive relationships between individuals and their context and, thus, supporting adaptive development [2]. Considering the above, positive youth development evolves as a framework that emphasizes the promotion of capacities by means of engaging and caring environments and creating opportunities for bidirectional and beneficial youth-context relationships rather than focusing on deficits [3-5]. Such an approach goes beyond single-level efforts and addresses a complex interaction of levels [6] including family, peer, school, and community environments. It is based on the importance of a successful attainment of milestones in terms of psychosocial development involving, for instance, social, emotional, and behavioral skills [7]. In particular, developmental outcomes in the acquisition and improvement of these skills can be influenced by the interaction 
of youth development and characteristics of the learning environment. Indeed, educational environments that promote particular safety, support, and youth interaction and engagement with the school have a considerable impact on youth behavior, and therefore, create positive youth development [8]. In this regard, restorative practices provide a unique and hopeful approach to address reframing social connection and bolstering mental and emotional wellbeing in educational contexts.

Restorative practices have their origins in restorative justice, a way of mediating a conflict [9] that allows those who may have committed harm to take responsibility for their acts by focusing on the victim and giving him/her a voice [10]. The principles of restorative justice are: (a) harm and related needs (victims, communities, and offenders); (b) obligations that have resulted from (and given rise to) this harm (offenders and communities); and (c) engagement of those who have a legitimate interest in the offense and its resolution (victims, offenders, and community members) [11]. The notions of the original framework of restorative justice are the central basis of the implementation of restorative approaches in many schools of many countries. Restorative approaches in schools involve pocket restorative approaches and Whole School Restorative Approaches (WSRA) [12]. While pocket school restorative approaches are implemented to deal with conflicts by means of responsive restorative practices such as mediation, restorative circles, or conferencing, WSRA go further and aim to promote a more inclusive and beneficial school culture $[13,14]$ that involves a reorientation of the management of relationships and conflicts and considers and validates the whole school community's experiences and needs [15,16]. They are in line with the positive youth development framework since they promote the relationship of all school community actors and address the interaction of individual motivation, attitudes, and behaviors, as well as social interaction, curriculum, pedagogical practices, neighborhood contexts, and educational systems $[17,18]$. By means of creating opportunities for bidirectional and beneficial youth-context relationships, they improve school community relationships and promote social and emotional skills including, for instance, self-regulation, self-management, emotional regulation skills, and empathy [19]. Improvement of school community relationships and social and emotional skills are both core components for positive youth development [20]. WSRA involve a comprehensive set of components and practices. Along with responsive restorative practices, they include the proactive type such as community-building circles. That is, active and participatory methodologies aimed at the development of social and emotional skills, group cohesion, or preventive measures for conflicts including bullying [21]. The importance of WSRA implementation has been strengthened by longitudinal studies showing promising outcomes for changing school climate and promoting positive relationships while improving people's senses of belonging and decreasing conflicts $[6,15]$.

Although there are a few literature reviews on the implementation of restorative approaches in schools, none of them seem to focus specifically on WSRA. In addition, those systematic literature reviews seem to be restricted in terms of the databases and search terms used [14], outcomes [22], country [23], type of data [24,25], as well as date and restorative components and practices [26]. The main aim of this study is to carry out a broad and systematic review to study the effectiveness of implementing WSRA with validity and quality. A second aim of the study is to develop and grade some educational practice guidelines based on the scientific evidence available on the effects of these approaches in schools. This would allow readers to understand the robustness of the developed practice guidelines for potential use in their own local settings. A reader may be able to identify the school setting, audience, and robustness of various WSRAs and make evidence-informed decisions in a timely manner. To our knowledge, such an initiative has not yet been carried out. Evidence-based practice guidelines are important to the educational community. Their use could facilitate educational decision making, optimize the use of available school resources, and improve the quality of education for the whole school community, adapting the interventions to their needs. Finally, they could help engage students in the school community and enhance their strengths and, thus, promote their positive development. 


\section{Materials and Methods}

A systematic literature review is considered a compilation of research results carried out to previous criteria and in order to answer a research question. In order to be valid and of quality, a systematic literature review must be based on neutral criteria that enable the procedure to have clarity, transparency, and accuracy. We used a type of systematic review known as a scoping review which is generally used when a body of evidence has not yet been fully reviewed, or exhibits a great, compounded, or diverse nature not manageable to a more specific systematic review. The review was conducted considering the Preferred Reporting Items for Systematic Reviews and Meta-Analyses (PRISMA) guidelines [27].

\subsection{Literature Search}

Literature searches were designed to be as sensitive as possible in order to obtain as many papers as possible on the effects of WSRA in schools. In order to locate and identify significant studies meeting the inclusion criteria, we carried out focused searches in the general literature. Inclusion criteria were all types of study designs (i.e., meta-analyses, systematic reviews, randomized controlled trials, case-control studies, cohort studies, nonanalytic studies, and expert opinions) intended to study the implementation of WSRA in schools in primary and/or secondary education and considering any member of a school community (i.e., students, teachers, and/or families). One should note that designs with a high methodological level in the field of WSRA in schools are scarce; therefore, we considered all types of study designs in order to be able to reach all the scientific evidence available. We only considered studies published in peer-review journals, as in these journals papers are peer-reviewed, and thus, the evidence of the studies they publish is of high quality. We did not consider studies: (a) focused on pocket school restorative approaches because they aim to solve conflicts, and only when integrated with WSRA they promote positive youth-development; (b) on the effects of WSRA implementation in non-ordinary schools (e.g., special schools) since participants may have other needs beyond those of students in ordinary schools, which could make the integration of results difficult; and (c) published in journals with no peer-review. Therefore, dissertations, books, or magazines were not included. There were no time or language limits.

We conducted a computerized search to identify articles about the efficacy of WSRA in schools. Specifically, we conducted our computerized search in ProQuest (PsycINFO, Educational Resources Information Centre or ERIC, Social Services Abstracts, and Sociological Abstracts), PubMed, and Education Full-Text in November 2021. We used the following terms to conduct the search: "restorative", "justice", "practice", "circle", "conference", "mediation", and "school". The standard search strategy was as follows: restorati * AND justice OR practice * OR circle * OR conference * OR mediat * AND school *. In order to confirm the suitability of our search strategy, we compared the records retrieved in the databases with those published in high-impact journals where papers in this field may be presented. We also checked specialized websites such as National Educators for Restorative Practices, The International Institute for Restorative Practices, The Restorative Justice Council, Transforming Conflict, and The Schott Foundation. We additionally compared the records retrieved with others regarding systematic reviews close to the field of our study [14,22-26]. We further reviewed the records of the identified articles. The search strategies may be redundant since they covered much of the same literature.

\subsection{Analytic Method}

This method has been used and considered valid for systematic reviews as an aid to determine the most highly rigorous evidence based on WSRA [28]. Specifically, it was intended to go through the internal validity of studies on the efficacy of the implementation of WSRA (see next section). To do so, we developed 15 research questions. We completed a cross tabulation of each selected study by 39 response categories in order to get frequencies and percentages of each of them. 
1. When were the studies conducted? The year when the study results were published was identified.

2. Where were the studies conducted? The country where the study was conducted was identified.

3. What was the range of the sample of target studies? The sample size across studies of target participants was identified.

4. What was the setting of studies? Studies were assigned to one of the following categories: (a) primary education; (b) secondary education; and (c) both.

5. Was there ethnic diversity in the context in which the WSRA was implemented? If so, how many ethnic groups were included in each study sample? Frequencies and percentages of studies conducted in contexts with ethnic diversity were calculated. The frequencies and percentages of the different ethnic groups in each study were categorized as follows: (a) two; (b) three; and (c) four or more.

6. What type of research design was used? The frequencies and percentages of research design used were identified and categorized as follows: (a) systematic literature review; (b) randomized controlled trial; (c) quasi-experimental study with control group; (d) quasi-experimental study without control group; (e) qualitative study; and (f) case study.

7. How long was the WSRA implemented for? Studies were assigned to one of the following categories: (a) one year or less; (b) from one year to two years; and (c) more than two years. The range of time of implementation of the studies was considered.

8. What type of follow-up was used in the studies? Studies were assigned to one of the following categories: (a) no follow-up; (b) pre and post measurements; (c) pre and post measurement, and follow-ups.

9. Which WSRA was implemented? The frequencies and percentages of each WSRA implemented were calculated. The WSRA implemented was identified across studies and essential elements were extracted.

10. What were the main outcomes of studies? Studies were assigned to one or more of the following categories: (a) classroom climate; (b) school climate; (c) social skills; (d) emotional skills; (e) behavior (risk behaviors, disruptive behaviors, playground incidents, use of first aid kit, conflicts and bullying); (f) disciplinary measures (discipline referrals, exclusions... ); (g) wellbeing and psychological wellbeing; (h) academic achievement; and (i) satisfaction with WSRA.

11. According to setting, were the WSRA reported to be effective? For each study we indicated if there were positive changes to one or more of the following categories: (a) classroom climate; (b) school climate; (c) social skills; (d) emotional skills; (e) behavior (risk behaviors, disruptive behaviors, playground incidents, use of first aid kit, conflicts and bullying); (f) disciplinary measures (discipline referrals, exclusions... ); (g) wellbeing and psychological wellness; (h) academic achievement; and (i) satisfaction with WSRA. Then, studies were classified into one of the following categories: (a) effective; (b) effective to some extent (at least in one outcome category); and (c) no effective.

12. Did the study use fidelity measures for the implementation of the WSRA?

13. Did the study use validated and reliable measures for the assessment of outcomes?

14. What was the level of evidence provided by each study? The study quality was evaluated using the Scottish Intercollegiate Guidelines Network or SIGN [29]. Studies were assigned to one of the following categories: (1) $1++$; (2) $1+$; (3) $1-$; (4) $2++$; (5) $2+$; (6) $2-$; (7) 3 ; and (8) 4.

15. Was there enough evidence to develop evidence-based practice guidelines? Practice guidelines were prepared using the SIGN [29]. Practice guidelines were assigned to one of the following grades: (1) A; (2) B; (3) C; (4) D.

To address questions 14 and 15, we used the SIGN method [29] as described in Table 1. This method is intended for the evaluation of the quality of the evidence of research studies, or in other words, it establishes the degree of confidence we can have in the results of 
selected studies. To do so, it considers the rigorousness of the study design as well as the risk of bias and the probability that there is a causal relationship between intervention and effect. Specifically, there are specific checklists according to study design to assess the internal validity of studies including items such as the clarity and appropriateness of the research question addressed, sample details (e.g., selection, size, baseline differences between groups, location, participants lost to follow-up, etc.) confounding variables, and statistical analyses. The checklists also allow for an overall assessment of studies. It establishes eight levels of evidence in a range from 1++ ("High-quality meta-analyses, systematic reviews of randomized controlled trials or randomized controlled trials with a very low risk of bias") to 4 ("Expert opinion"). The lower the score is, the higher the quality of evidence. Considering the level of evidence of the selected studies, the SIGN method [29] enables the preparation of evidence-based practice guidelines. It takes into account the applicability of results to the target population, the amount of evidence available and the consistency of results. It establishes 4 grades of practice guidelines in a range from A ("At least one meta-analysis, systematic review or randomized controlled trial rated as $1++$ and directly applicable to the target population; or a body of evidence consisting principally of studies rated as $1+$, directly applicable to the target population and demonstrating overall consistency of results") to D ("Evidence level 3 or 4; or extrapolated evidence from studies rated as 2+). To answer question 14 , study quality was evaluated independently by pairs (VK and LME). Disagreements between evaluators were resolved by discussion and consensus by a third investigator (JAAC). To address question 15, we developed evidence-based practice guidelines following the described system.

Table 1. Key to evidence statements and grades of recommendation by the Scottish Intercollegiate Guidelines Network (SIGN).

\begin{tabular}{|c|c|}
\hline \multicolumn{2}{|r|}{ Levels of Evidence } \\
\hline $1++$ & $\begin{array}{l}\text { High-quality meta-analyses, systematic reviews of RCTs }{ }^{\text {a }} \text { or RCTs with a very } \\
\text { low risk of bias }\end{array}$ \\
\hline $1+$ & Well-conducted meta-analyses, systematic reviews or RCTs with a low risk of bias \\
\hline $1-$ & Meta-analyses, systematic reviews or RCTs with a high risk of bias \\
\hline $2++$ & $\begin{array}{l}\text { High-quality systematic reviews of case-control or cohort studies. High-quality } \\
\text { case-control or cohort studies with a very low risk of confounding or bias and a high } \\
\text { probability that the relationship is causal }\end{array}$ \\
\hline $2+$ & $\begin{array}{l}\text { Well-conducted case-control or cohort studies with a low risk of confounding or bias and a } \\
\text { moderate probability that the relationship is causal }\end{array}$ \\
\hline $2-$ & $\begin{array}{l}\text { Case control or cohort studies with a high risk of confounding or bias and a significant risk } \\
\text { that the relationship is not causal }\end{array}$ \\
\hline 3 & Non-analytic studies, e.g., case reports, case series \\
\hline 4 & Expert opinion \\
\hline \multicolumn{2}{|r|}{ Grades of Recommendation } \\
\hline A & $\begin{array}{l}\text { At least one meta-analysis, systematic review or RCT rated as } 1++ \text { and directly applicable to } \\
\text { the target population; or a body of evidence consisting principally of studies rated as } 1+, \\
\text { directly applicable to the target population and demonstrating overall consistency of results }\end{array}$ \\
\hline B & $\begin{array}{c}\text { A body of evidence including studies rated as } 2++ \text {, directly applicable to the target } \\
\text { population and demonstrating overall consistency of results; or extrapolated evidence from } \\
\text { studies rated as } 1++ \text { or } 1+\end{array}$ \\
\hline $\mathrm{C}$ & $\begin{array}{c}\text { A body of evidence including studies rated as } 2+\text {, directly applicable to the target } \\
\text { population and demonstrating overall consistency of results; or extrapolated evidence from } \\
\text { studies rated as } 2++\end{array}$ \\
\hline $\mathrm{D}$ & Evidence level 3 or 4 ; or extrapolated evidence from studies rated as $2+$ \\
\hline
\end{tabular}


Inter-rater agreement was established between two members of the research team (VK and LME) in order to assess the proportion of agreement when determining levels of evidence and grades of practice guidelines. Both of them extracted data from the included articles and coded studies considering the parameters of our research questions. Agreement was considered acceptable if it met at least $80 \%$ [30]. Six studies (46\%) were randomly selected and both investigators extracted data independently and added them to a codebook. Such data was assessed for consistency between the two evaluators by calculating the proportion of agreements and disagreements on the different codes. Interrater agreement was $97.4 \%$. Cohen's Kappa was not estimated due to the scarce variability of agreement between both evaluators [31].

\section{Results}

\subsection{Overall Results}

We identified a total of 7775 records by means of the computerized search. We did not identify more records in the manual search (See Figure 1). After eliminating duplicates, we excluded 7658 that did not meet inclusion criteria. Most of the studies excluded were out of scope since they cover literature on engineering, dentistry, palliative care, health care services, eating disorders, LGBT student experiences, divorce, forensic evaluation, prisons, criminal behavior, consumer satisfaction or consumer attitudes, among others. We ultimately included 13 studies.

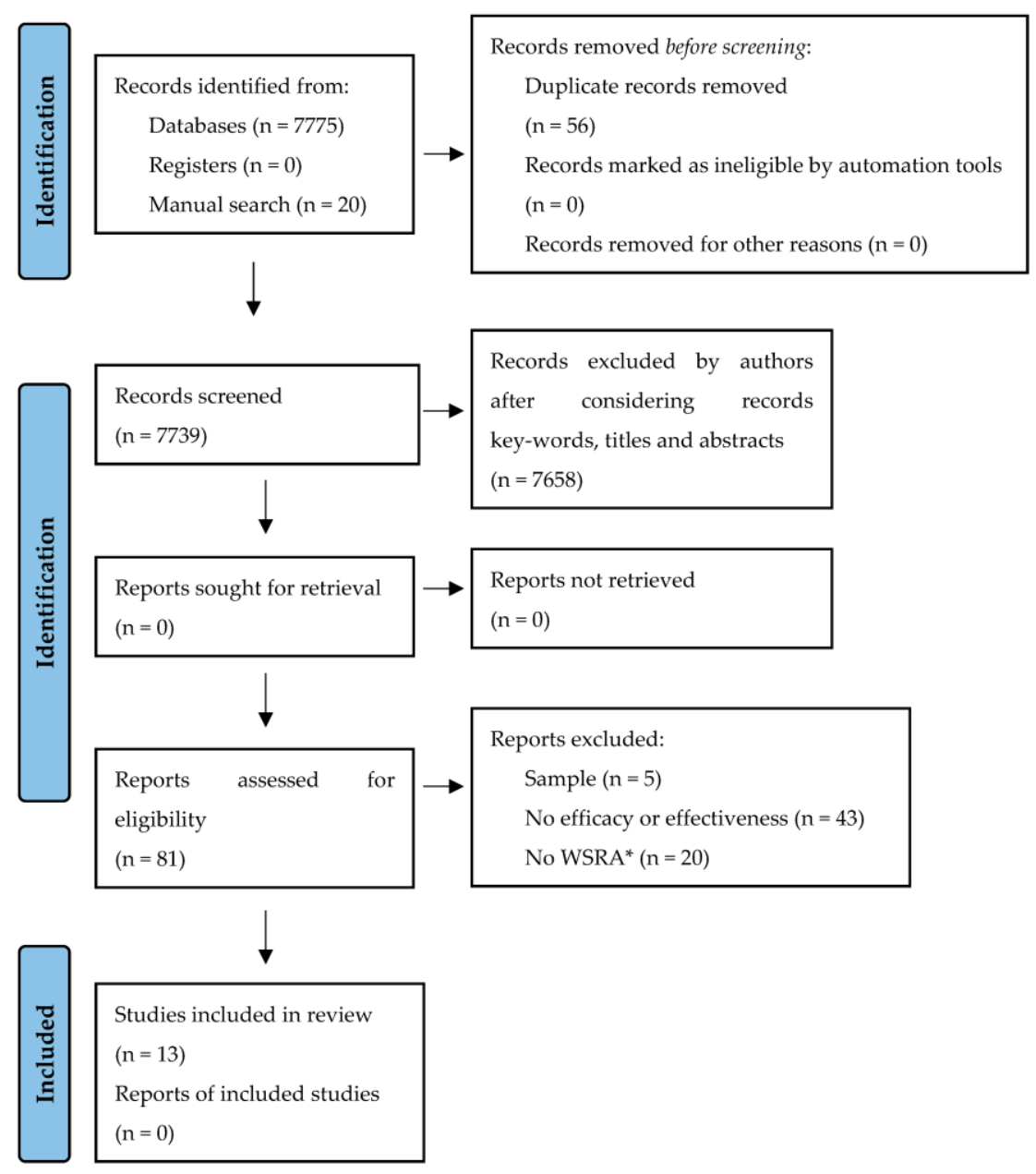

*WSRA: Whole School Restorative Approach

Figure 1. Search and inclusion processes flowchart. 


\subsection{Analytic Method: Research Questions and Responses}

Appendix A shows the main characteristics of the papers identified. Most of the studies were published between 2015 and $2020(69.2 \%)$ and were conducted in the United States of America (38.5\%), United Kingdom (30.8\%), and Australia (15.4\%).

As for the sample characteristics, five (38.5\%) studies were conducted with students with a sample range from 40 to 2771 , two $(15.4 \%)$ with school staff with a sample range from 6 to 95 , two studies (15.4\%) included both students and school staff with a sample range from 14 to 412 , three $(23.1 \%)$ included both students and school staff but did not specify the sample size and $1(7.7 \%)$ included students but the sample size was not specified either. Eight studies $(61.5 \%)$ were conducted in secondary education, two studies $(15.4 \%)$ in primary education and the rest $(3 ; 23.1 \%)$ in primary and secondary education.

Eight studies (61.5\%) reported ethnic diversity in the setting where the WSRA was implemented, while the rest of studies (38.5\%) did not report data on this dimension. Of those reporting data on ethnic diversity, four studies (50\%) included more than four ethnic groups and four studies (50\%) did not report data on the number of ethnic groups included.

They included a total of seven quasi-experimental studies (53.8\%), four qualitative studies (30.8\%), and two randomized controlled trials (15.4\%). With regard to a follow-up, seven studies (53.8\%) considered post-intervention measures, five (38.5\%) pre- and postmeasures, and one (7.7\%) pre-, post-, and follow-up measures at 24 and 36 months. As for the time of implementation of the different WSRA across studies, six studies (46.2\%) implemented the WSRA for more than two years, five (38.5\%) within one year and two years, and two $(15.4 \%)$ less than one year. The time of implementation of the different approaches ranged from 6 months to 5 years.

Four studies (30.8\%) included WSRA based on the essential elements stated by the International Institute of Restorative Practices model, and two studies (15.4\%) the Learning Together Intervention. The remaining seven studies (53.8\%) incorporated different approaches (i.e., the Whole School Restorative Approach, the Restorative Practice Approach, Restorative Approach based on the European Forum for Restorative Justice, the Traditional Whole School approach and the Proactive-only Whole School Approach at the same time, the Restorative Justice approach as part of the Safe Schools initiative, the Pilot Community Conferencing and Restorative Practices Program, and The Restorative Whole-School Approach).

As for outcomes, four studies (30.8\%) included school engagement, one $(7.7 \%)$ classroom climate, four $(30.8 \%)$ school climate, two $(15.4 \%)$ values, seven $(53.8 \%)$ social skills, six (46.2\%) emotional skills, six (46.2\%) behavior, three (23.1\%) disciplinary measures, and three $(23.1 \%)$ wellbeing. Twelve $(92.3 \%)$ studies reported positive changes associated with the implementation of the WSRA. When reporting positive results, two (15.4\%) studies did so with regard to school engagement, one $(7.7 \%)$ classroom climate, two $(15.4 \%)$ school climate, two (15.4\%) values, six (46.2\%) social skills, five (38.5\%) emotional skills, six (46.2\%) behavior, three $(23.1 \%)$ disciplinary measures, and three $(23.1 \%)$ wellbeing. Ten studies $(76.9 \%)$ were reported to be effective in all included outcomes, two $(15.4 \%)$ were effective only in some of them, and one $(7.7 \%)$ study was not effective in any of them. Three studies (23.1\%) used fidelity measures for the assessment of the WSRA implementation, while ten $(76.9 \%)$ did not consider fidelity measures. Six (46.2\%) studies used questionnaires and four of them $(66.7 \%)$ were reported to be valid and reliable.

Taking into account the results of our analytic method, there was enough scientific evidence to develop evidence-based practice guidelines on the effects of the implementation of WSRA in schools. Out of the thirteen studies, twelve (92.3\%) were considered for the preparation of practice guidelines since one study $(7.7 \%)$ did not show positive changes associated with the WSRA implementation. The grade of practice guidelines ranged from $D$ to A: D, 8 practice guidelines $(80 \%)$; B, 1 practice guideline $(10 \%)$, and A, 1 practice guideline $(10 \%)$. Out of the ten practice guidelines, $2(20 \%)$ were related to primary education, $5(50 \%)$ to secondary, and $3(30 \%)$ to both school settings. In addition, $2(20 \%)$ practice guidelines 
were related to the implementation of the Learning Together Intervention and $8(80 \%)$ to other specific WSRA. See Appendix A for more details of studies.

\subsection{Whole-School Restorative Approaches: Evidence Available, Its Quality and Development of Evidence-Based Guidelines}

In this section, we present in detail the scientific evidence identified and show that, according to the SIGN methodology [29], its quality is high enough to develop evidencebased guidelines.

With regard to primary education, two studies were selected. Goldys (2016) [32] prepared a report on the effects of the Whole School Restorative Approach after four years of implementation. It was based in the USA and the entire school community was considered in the sample although its size was not stated. It included a diverse population of students. By means of post-intervention measures, the results showed that the WSRA was associated with improvement and enduring changes in behavior (level of evidence: 3 ). In Canada, Reimer (2011) [33] conducted a qualitative study at a primary school with a diverse community of students on the effects of the Restorative Justice Approach as part of the Safe Schools Initiative after 5 years of its implementation. The study sample included one school administrator, one board administrator and four teachers. There was no followup. The results showed that the intervention seemed to be associated with benefits for students in providing character education, valuing students as individuals, listening to their voices and giving them ownership of the issue and assisting in healing relationships. An improvement in classroom climate and the whole school climate was also observed (level of evidence: 3 ). Both studies are non-analytic and have a risk of bias. They allow the preparation of two low grade practice guidelines as follows:

- The Whole School Restorative Approach as the behavior plan to change school culture is recommended in primary education to improve behavior in settings with a diverse population of students and in the long term [32] (Grade of recommendation: D).

- The Restorative Justice Approach as part of the Safe Schools Initiative is recommended in primary schools characterized by a diverse community of students to provide character education; valuing students as individuals, listening to their voices and giving them ownership of the issue and assisting in healing relationships in the long term. It is also recommended for the improvement of classroom and whole school climate in the long term [33] (Grade of recommendation: D).

Regarding secondary education, we identified eight studies. Two of them were related to the so-called Learning Together Intervention. Bonell et al. (2018) [34] conducted a study on the Learning Together Intervention that included 7121 students in secondary schools with a high degree of diversity in terms of ethnicity and a three-year follow-up. The intervention had a small but significant effect on bullying but no effect on aggression at 24 months' follow-up. At 36 months' follow-up, the intervention group showed higher quality of life and psychological well-being and lower psychological difficulties than the control group. The intervention was also associated with reductions in police contact, smoking and alcohol and drug use (level of evidence: 1++). Warren et al. (2020) [35] conducted a qualitative study on the Learning Together Intervention within the aforementioned controlled trial. No details were reported on the sample participating which included students and staff. By means of post-intervention measures, the results showed that The Learning Together Intervention helped to create a more inclusive and cohesive school environment (level of evidence: 3 ). While the first study is a randomized control trial design with low risk of bias; the second study includes a non-analytic design and, thus, has a risk of bias. Considering the different level of evidence of both studies, two practice guidelines are prepared since an integrated recommendation on the Learning Together Intervention cannot be prepared. The practice guidelines are as follows: 
- The Learning Together Intervention is recommended, in the long term, in order to decrease bullying while improving quality of life, psychological well-being and psychological difficulties of students in secondary schools with high levels of student diversity. It is also recommended in order to reduce police contact, smoking and alcohol and drug use in the long term [34] (Grade of recommendation: A).

- The Learning Together Intervention is recommended in secondary schools with high levels of student diversity to create a more inclusive and cohesive school environment in the long term [35] (Grade of recommendation: D).

Another study conducted in secondary education is that of Wong et al. (2011) [36]. It used a quasi-experimental design to study the effectiveness of The Restorative WholeSchool Approach after two years of implementation. It was based in Hong Kong and included a control and a partial group, pre-and post-measures and a sample size of about 1200 students. The pre- and post-measures showed a significant reduction in bullying in the intervention group and higher social and emotional skills in comparison with both control groups (level of evidence: $2++$ ). This quasi-experimental study shows a very low risk of bias and a high probability that the relationship is causal. One practice guideline is prepared on The Restorative Whole-School Approach model of Wong et al. (2011) [36]:

- The Restorative Whole-School Approach model is recommended for students in secondary schools in order to reduce bullying and increase empathy and self-esteem in the medium term [36] (Grade of recommendation: B).

Four studies on the effectiveness of WSRA including the essential elements as described by The International Institute of Restorative Practices Model were identified. Acosta et al. (2019) [6] conducted a randomized controlled trial on the efficacy of Restorative Practices Intervention that included 2771 students in secondary schools, with high levels of diversity in terms of ethnicity, and pre- and post-intervention measures after two years of implementation. There were no differences between the study groups in school connectedness, positive developmental outcomes and bullying victimization (level of evidence: 1+). Gregory et al. (2015) [37] conducted a quasi-experimental study in the USA one year after the WSRA was implemented. It included a control group, a sample size of 412 ethnically diverse students from secondary schools, and post-intervention measures. Their results showed that higher implementation levels of the WSRA were associated with better teacher-student relationships. Students perceived teachers as more respectful, and they issued fewer discipline referrals compared with low intervention implementation (level of evidence: 2+). Mansfield et al. (2018) [13] prepared a report on a WSRA, after two years of implementation, in the USA in a school that enrolls a diverse student body. It included pre- and post-measures but no control group. The number of participants was not stated in the paper. The results showed a decline in in-school and out-of-school suspensions and a decrease in the discipline gaps across race/ethnicity, gender and special education (level of evidence: 2-). Mirsky (2007) [38] prepared another report in the USA within a range from two to four years after the WSRA was implemented. It included a large sample size ( $n=2148$ students) at three secondary schools. The results found the WSRA to be associated with a decrease in disciplinary referrals, detentions, incidents of disruptive behavior, and out-of-school suspensions in post-intervention measures. There was also an establishment of a culture of collaboration among staff and a significant increase in students reporting other students for behavioral problems, students self-reporting, and parents reporting their children (level of evidence: 3 ).

There is a well-conducted cohort study with a low risk of confounding or bias and a moderate probability that the relationship is causal [37]. The remaining studies selected are non-analytic studies. The evidence available on the effectiveness of WSRA including the essential elements of the International Institute of Restorative Practices Model allows for an integrated practice guideline. Therefore, one specific practice guideline is prepared according to study outcomes: 
- The WSRA including the essential elements of the International Institute of Restorative Practices Model is recommended in ethnically diverse secondary schools, to improve teacher-student relationships while decreasing exclusionary discipline referrals in the medium term; to reduce in-school and out-of-school suspension rates as well as the number of infractions leading to suspension and the discipline gaps, to decrease exclusionary discipline referrals and detentions, to improve teacher-student relationships, and to improve collaboration among staff members in the medium and long term [13,37,38] (Grade of recommendation: D)

The last of the studies regarding secondary education is that conducted by Norris (2019) [12] on the effectiveness of the Traditional Whole School Approach versus the Proactive-only Whole School Approach after 18 months of implementation by means of a quasi-experimental design. This study was conducted in the United Kingdom with a comparison of the aforementioned WSRA and a sample of about 600 students. The Proactiveonly Whole School Approach showed higher levels of happiness and school engagement in comparison with the Traditional Whole School Approach (level of evidence: $2-$ ). This is a case-control study with a high risk of confounding or bias and a significant risk that the relationship is not causal. The resulting practice guideline is formulated as follows:

- The Proactive-only Whole School Approach is recommended in secondary schools to increase levels of happiness and school engagement in the medium term [12] (Grade of recommendation: D).

As for studies conducted in primary and secondary education at the same time, we identified three studies including three different WSRA. Moir and MacLeod (2018) [39] conducted a quasi-experimental study on the effectiveness of the Restorative Approach based on the model of Education Scotland (2015) after 6 months of implementation and included 18 multiagency partners. Post-intervention measures showed that Educational Psychology Services that implemented the aforementioned WSRA were associated with an improvement in relationships and a reduction in exclusions/referrals to alternative schools (level of evidence: 3). Kehoe et al. (2008) [40] conducted a qualitative study in Australia on the effectiveness of the Restorative Practice Approach after at least 5 years of implementation in schools that had diverse ethnic populations. It included a sample size of 54 participants together with teachers and students. Their post-intervention measures showed that the implementation of the WSRA was associated with better student behavior as well as enhanced social and emotional skills (level of evidence: 3). Shaw (2007) [41] carried out a qualitative study on the effectiveness of the Pilot Community Conferencing and Restorative Practices Program in Australia, after two years of its implementation, that included 18 primary and secondary schools and post-intervention measures. The sample size was not stated in the study. The results showed that such a program can be effective for repairing relationships, acknowledging consequences of behavior, and resolving disputes. For teachers and administrators, the program represented a shift in thinking with regard to justice and discipline (level of evidence: 3 ).

The evidence identified on those three specific WSRA for primary and secondary education had a high risk of confounding or bias and the relationship studied may not be causal. The following three specific practice guidelines are prepared:

- Restorative Approaches of Education Scotland is recommended in primary and secondary education to improve relationships and reduce exclusions/referrals to alternative schools in the short term [39] (Grade of recommendation: D).

- The Restorative Practice Approach is recommended in primary and secondary schools with diverse ethnic populations to improve student behavior and social and emotional skills in the long term [40] (Grade of recommendation: D).

- Pilot Community Conferencing and Restorative Practices Program is recommended in primary and secondary schools in order to repair relationships, acknowledge consequences of behavior and resolve conflicts in the medium term [41] (Grade of recommendation: D). 
Table 2 includes the details of the approaches identifies and their corresponding practice guidelines.

Table 2. Details and practice guidelines of Whole School Restorative Approaches.

\begin{tabular}{|c|c|c|c|}
\hline Name of Approach & Essential Elements & Practice Guideline & $\begin{array}{c}\text { Grade of } \\
\text { Recommendation }\end{array}$ \\
\hline \multicolumn{4}{|c|}{ Primary education } \\
\hline $\begin{array}{l}\text { Whole School } \\
\text { Restorative Approach }\end{array}$ & $\begin{array}{ll}\text { - } & \text { Circles: Community circles, justice circle, } \\
\text { academic circle, faculty circle and family circle } \\
\text { - } \quad \text { Virtues language } \\
\text { - } \quad \text { Practice what you preach } \\
\text { - } \quad \text { Problem-solving factory } \\
\text { - } \quad \text { Virtue assemblies } \\
\text { - } \quad \text { Clubs } \\
\text { - } \quad \text { Civic projects } \\
\text { - } \quad \text { Parent engagement } \\
\text { - } \quad \text { Norwood STREAM project bus }\end{array}$ & $\begin{array}{l}\text { It is recommended in primary } \\
\text { education setting with a diverse } \\
\text { population of students to improve } \\
\text { behavior in the long term [32]. }\end{array}$ & $\mathrm{D}$ \\
\hline $\begin{array}{l}\text { Restorative Justice } \\
\text { Approach as part of the } \\
\text { Safe Schools Initiative }\end{array}$ & $\begin{array}{l}\text { Restorative approach: } \\
\text { - } \quad \text { Use of restorative circles with students and } \\
\text { teachers that aimed to gather information about } \\
\text { their perspective on the school environment. } \\
\text { During } 45-90 \text { min sessions, students facilitated } \\
\text { circles on conflict management and } \\
\text { peer relationships. } \\
\text { Other approaches: } \\
\text { - All teachers at the School had been trained in the } \\
\text { Tribes Learning Communities program. Tribes is } \\
\text { a program that began in the } 1970 \text { s and, } \\
\text { according to the Tribes 'Website, is a } \\
\text { research-based process that creates a culture that } \\
\text { maximizes learning and human development. It } \\
\text { is a step-by-step process that teachers implement } \\
\text { in their classrooms to teach students skills to } \\
\text { enable them to work collaboratively in } \\
\text { long-term groups called Tribes }\end{array}$ & $\begin{array}{l}\text { It is recommended in primary schools } \\
\text { to provide character education; } \\
\text { valuing students as individuals, } \\
\text { listening to their voices and giving } \\
\text { them ownership of the issue and } \\
\text { assisting in healing relationships. It is } \\
\text { also recommended for the } \\
\text { improvement of classroom and whole } \\
\text { school climate [33]. }\end{array}$ & $\mathrm{D}$ \\
\hline
\end{tabular}

Secondary education

\begin{tabular}{|c|c|c|c|c|}
\hline \multicolumn{5}{|c|}{ Secondary education } \\
\hline $\begin{array}{l}\text { The Learning Together } \\
\text { Intervention }\end{array}$ & $\begin{array}{l}- \\
- \\
-\end{array}$ & $\begin{array}{l}\text { Primary restorative practices using respectful } \\
\text { language to challenge or support behavior and } \\
\text { circle time to build relationships. } \\
\text { Secondary restorative practices involved } \\
\text { implementing restorative conferences to address } \\
\text { more serious behavior problems. } \\
\text { Lesson plans and slides to guide teachers' } \\
\text { delivery of 5-10 h per year of lessons on social } \\
\text { and emotional skills for students. } \\
\text { Action group meetings of at least six staff and six } \\
\text { students, held twice per term, to review relevant } \\
\text { school policies and coordinate the intervention. }\end{array}$ & $\begin{array}{c}\text { It is recommended in order to } \\
\text { decrease bullying while improving } \\
\text { quality of life, psychological } \\
\text { well-being and psychological } \\
\text { difficulties of students in secondary } \\
\text { schools. It is also recommended in } \\
\text { order to reduce police contact, } \\
\text { smoking and alcohol and drug use } \\
\text { [34]. }\end{array}$ & $\mathrm{A}$ \\
\hline $\begin{array}{c}\text { The Restorative } \\
\text { Whole-School } \\
\text { Approach }\end{array}$ & $\begin{array}{l}- \\
- \\
- \\
- \\
- \\
-\end{array}$ & $\begin{array}{l}\text { Mediation services or restorative conferences for } \\
\text { resolving conflicts } \\
\text { School harmony programs such as drafting } \\
\text { antibullying policies } \\
\text { Workshops and talks for parents } \\
\text { Peace education curriculum } \\
\text { Students' competitions relating to building a } \\
\text { harmonious school } \\
\text { Training programs for general office staff } \\
\text { and janitors }\end{array}$ & $\begin{array}{l}\text { It is recommended for students in } \\
\text { secondary schools in order to reduce } \\
\text { bullying and increase empathy and } \\
\text { self-esteem [36]. }\end{array}$ & B \\
\hline
\end{tabular}


Table 2. Cont.

\begin{tabular}{|c|c|c|c|}
\hline Name of Approach & Essential Elements & Practice Guideline & $\begin{array}{c}\text { Grade of } \\
\text { Recommendation }\end{array}$ \\
\hline $\begin{array}{l}\text { The Learning } \\
\text { Together Intervention }\end{array}$ & 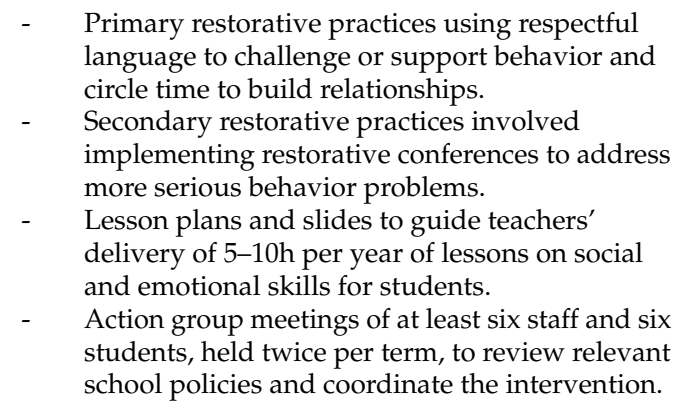 & $\begin{array}{l}\text { It is recommended in secondary } \\
\text { schools to create a more inclusive and } \\
\text { cohesive school environment [35]. }\end{array}$ & $\mathrm{D}$ \\
\hline $\begin{array}{l}\text { Whole School } \\
\text { Restorative Approaches } \\
\text { including the essential } \\
\text { elements of the } \\
\text { International Institute } \\
\text { of Restorative } \\
\text { Practices Model }\end{array}$ & $\begin{array}{ll}\text { - } & \text { Affective statements } \\
- & \text { Restorative questions } \\
- & \text { Small conferences } \\
- & \text { Proactive circles } \\
- & \text { Responsive circles } \\
\text { - } & \text { Restorative conferences } \\
- & \text { Fair process } \\
- & \text { Reintegrative management of shame } \\
- & \text { Restorative staff community } \\
- & \text { Restorative approach with families } \\
- & \text { Fundamental hypothesis }\end{array}$ & $\begin{array}{l}\text { It is recommended in ethnically diverse } \\
\text { secondary schools, to improve } \\
\text { teacher-student relationships while } \\
\text { decreasing exclusionary discipline referrals } \\
\text { in the medium term; to reduce in-school } \\
\text { and out-of-school suspension rates as well } \\
\text { as the number of infractions leading to } \\
\text { suspension and the discipline gaps, to } \\
\text { decrease exclusionary discipline referrals } \\
\text { and detentions, to improve teacher-student } \\
\text { relationships, and to improve collaboration } \\
\text { among staff members in the medium and } \\
\text { long term }[13,37,38] \text {. }\end{array}$ & $\mathrm{D}$ \\
\hline $\begin{array}{l}\text { Traditional Whole } \\
\text { School Approach and } \\
\text { Proactive-only Whole } \\
\text { School Approach }\end{array}$ & $\begin{array}{l}\text { School A: Traditional Whole School Approach: } \\
\text { - } \quad \text { Proactive practices are not specified but limited } \\
\text { in scope } \\
\text { - Reactive practices incllude } \\
\text { informal conferencing } \\
\text { School B: Proactive-only Whole School Approach: } \\
\text { - } \quad \text { RA Officer's main role was to train the staff } \\
\text { members in proactive classroom practices } \\
\text { Once all members of staff were trained to this } \\
\text { level, principally during school in-service days, } \\
\text { subsequent evening sessions were made } \\
\text { available to those who wished to pursue further } \\
\text { instruction on restorative practices } \\
\text { Implementation of positive communication } \\
\text { strategies between staff and students within the } \\
\text { everyday discourse of school interactions, } \\
\text { utilizing enquiring questions, and student-led } \\
\text { participation strategies. }\end{array}$ & $\begin{array}{c}\text { The Proactive-only Whole School } \\
\text { Approach is recommended in } \\
\text { secondary schools to increase levels of } \\
\text { happiness and school engagement } \\
\text { [12]. }\end{array}$ & $\mathrm{D}$ \\
\hline \multicolumn{4}{|c|}{ Primary and secondary education } \\
\hline $\begin{array}{c}\text { Restorative Practice } \\
\text { Approach }\end{array}$ & $\begin{array}{l}\text { - The approach aims to deal with student behavior } \\
\text { in a holistic way through increasing social and } \\
\text { emotional skills in students and staff as well as } \\
\text { handling behavioral incidents as they arise } \\
\text { - } \quad \text { Holistic approach that uses modeling pro-social } \\
\text { behaviors and a common language that avoids } \\
\text { focusing on blame or excuses } \\
\text { - A continuum incorporating both reactive and } \\
\text { proactive approaches }\end{array}$ & $\begin{array}{l}\text { This approach is recommended in } \\
\text { primary and secondary education to } \\
\text { improve student behavior and social } \\
\text { and emotional skills [40]. }\end{array}$ & $\mathrm{D}$ \\
\hline
\end{tabular}


Table 2. Cont.

\begin{tabular}{|c|c|c|c|}
\hline Name of Approach & Essential Elements & Practice Guideline & $\begin{array}{c}\text { Grade of } \\
\text { Recommendation }\end{array}$ \\
\hline & $\begin{array}{l}\text { - The reactive approach involves formally } \\
\text { bringing together the students in a conference, } \\
\text { after an incident has occurred, to discuss what } \\
\text { happened and how to resolve the issue. Teachers } \\
\text { ask students a series of affective questions when } \\
\text { reacting to these situations } \\
\text { Reactive approaches are enhanced through } \\
\text { proactive, holistic and relational style of } \\
\text { language to communicate with students. This is } \\
\text { achieved through the use of affective language. } \\
\text { Affective language involves using statements } \\
\text { about how someone was impacted by the other } \\
\text { person's behavior with the aim of } \\
\text { eliciting feelings. } \\
\text { Restorative conversations; restorative circles; } \\
\text { restorative conferences; and peer mediation. } \\
\text { Circle time. } \\
\text { - School staff modelling prosocial behavior, } \\
\text { affective language. } \\
\text { School staff following school policy. }\end{array}$ & & \\
\hline $\begin{array}{l}\text { Restorative Approach } \\
\text { based on Education } \\
\text { Scotland (2015) }\end{array}$ & $\begin{array}{l}\text { - It is an inclusive approach, consisting of } \\
\text { addressing harm or the risk of harm through } \\
\text { engaging all those affected in coming to a } \\
\text { common understanding and agreement on how } \\
\text { the harm or wrongdoing can be repaired, } \\
\text { relationships maintained and justice achieved. } \\
\text { The training was designed to understand values, } \\
\text { knowledge and skills that underpin restorative } \\
\text { practices, to encourage participants in a critical } \\
\text { enquiry into restorative practices, and to embed } \\
\text { what participants found valuable in their } \\
\text { daily practice. } \\
\text { Participants received training in the rationale for } \\
\text { formal restorative processes, including } \\
\text { restorative conversations and conversation } \\
\text { practice. The training also acknowledged that } \\
\text { restorative principles and practices can be used } \\
\text { in informal conversations and daily interactions } \\
\text { to strengthen relationships and build a culture of } \\
\text { respect within schools. } \\
\text { Themes explored: (a) paradigms of justice; (b) } \\
\text { the social discipline window; (c) the concept of } \\
\text { 'shame' and the relationship between this affect } \\
\text { and behavior using Tomkins' Theory of Affect; } \\
\text { and (d) key elements of active, empathic } \\
\text { listening skills, the importance of body language, } \\
\text { the use of reframing as a tool for acknowledging } \\
\text { and summarizing statements; (e) restorative } \\
\text { enquiry questioning and the conversation } \\
\text { process, and scenario practice. } \\
\text { The use of restorative circles, restorative } \\
\text { meetings and restorative conversations was } \\
\text { demonstrated and practiced. }\end{array}$ & $\begin{array}{l}\text { Restorative Approaches of Education } \\
\text { Scotland is recommended in primary } \\
\text { and secondary education to improve } \\
\text { relationships and reduce } \\
\text { exclusions/referrals to } \\
\text { alternative schools [39]. }\end{array}$ & $\mathrm{D}$ \\
\hline $\begin{array}{l}\text { Pilot Community } \\
\text { Conferencing and } \\
\quad \text { Restorative } \\
\text { Practices Program }\end{array}$ & $\begin{array}{l}\text { Restorative practices implementation within a } \\
\text { range including from conferencing to a broader } \\
\text { framework of relationship management and } \\
\text { social skill development }\end{array}$ & $\begin{array}{l}\text { WSRPA are recommended in primary } \\
\text { and secondary schools in order to } \\
\text { repair relationships, acknowledging } \\
\text { consequences of behavior and } \\
\text { resolving conflicts [41]. }\end{array}$ & $\mathrm{D}$ \\
\hline
\end{tabular}




\section{Discussion}

The objective of this study was to conduct a comprehensive and systematic literature review on the effects of WSRA in schools and develop evidence-based practice guidelines following the SIGN system [29]. The final aim of the study is to provide guidance on the effects of WSRA implementation on outcomes related to positive youth development.

Thirteen studies met the inclusion criteria and we developed 10 evidence-based practice guidelines on the implementation of WSRA considering the level of evidence: study design and intervention results. Most studies showed positive results associated with its implementation and, especially, on improving social and emotional skills and behavior. Those are key components of approaches directed at promoting positive youth development [20]. The results suggest that the WSRA provide a valuable framework that allows the development of successful restorative youth programs that improve conflict resolution skills, reduce discipline and disruptive problems, and enhance school attendance. Additionally, the WSRA approach improves communication competences and emotional literacy in teachers, other school staff, families, and students, which boosts both social-emotional development and long-term mental well-being in school-age children and adolescents. It is noteworthy that the WSRA have been used successfully in different cultural contexts, enhancing a school climate of equity, inclusion, and sensitivity to diversity where respect to the traditional ethnic culture of each school is fundamental. Even so, the evidence available does not allow for the preparation of general practice guidelines since we identified specific WSRA with specific components. This makes it difficult to integrate evidence on general practice guidelines.

When looking into specific WSRA, the highest level of scientific evidence is for secondary education. On the one hand, the Learning Together Intervention [34] is associated with improvements in quality of life and psychological wellbeing. It is also efficacious in reducing police contacts and substance use. There is also scientific evidence supporting another specific approach in secondary education, The Restorative Whole-School Approach [36] to decrease bullying while improving social and emotional skills. Again, outcomes considered key components of approaches aimed at promoting positive youth development [20]. These two WSRA are strongly recommended considering their grade of recommendation. As for the remaining approaches identified, further evaluation of their implementation is suggested in order to have more data to increase the grade of their evidence-based guidelines.

It is worth highlighting that only two randomized controlled trials have been conducted on WSRA. They are both based on secondary education. The first one evaluated the efficacy of the Learning Together Intervention [34] as already mentioned. This intervention includes not only restorative practice elements but also methods to modify school policies and systems and another for social and emotional education. Since some WSRA also include such methodology, this study was also considered in our review. The second study found that the Restorative Practices Intervention has no benefits over the control group [6]. This is probably because the control group had implemented restorative practices at some degree. Despite the above-mentioned limitations, this is not to say that such initiatives have no value. Firstly, they are the first randomized controlled trials conducted on WSRA. This is quite a challenge considering they both include more than 2000 students in secondary schools. The implementation of such designs in ordinary school settings is also a challenge given that daily life in schools is quite complex. Secondly, the experience of conducting such studies and their results establishes the conditions for more rigorous research and for a theoretical basis that supports the association of a positive school climate with positive youth development [6] and with the improvement of risk and health outcomes [34]. When looking into the body of evidence, the approaches including the essential elements of the International Institute of Restorative Practices Model are those that have more evidence on their effectiveness $[6,13,37,38]$. Most of the results indicate the effectiveness of such approaches in secondary schools in improving relationships while decreasing disciplinary measures. This is consistent with the need of school approaches to build positive rela- 
tionships and to resolve conflicts in a more proactive way [42]. An integrated practice guideline was prepared although its grade of recommendation suggests further research on its effectiveness.

Our review suggests the need for more rigorous methodological research concerning such approaches, but also the other identified WSRA and in primary and secondary education. On the one hand, more rigorous quasi-experimental studies and randomized controls are needed [8]. In this sense, it is also necessary to use evaluation measures within a psychometric analysis framework (i.e., validity, reliability, and responsiveness) [43] to evaluate the effects of WSRA and the use of blind raters to evaluate their effects to minimize biases. We also recommend a high degree of fidelity to the implementation of WSRA controlling the challenges that are involved (e.g., lack of staff buy-in) [8], as only a few studies did so since poor implementation may yield mixed outcomes [44]. The impact of the implementation of WSRA on outcomes such as academic achievement and satisfaction of participants is also suggested. They should address the limitations of those that have already been carried out [6] and provide a higher level of evidence of those with a low grade of recommendation. The lowest grade of recommendations does not support the use of a specific educational practice. Even so, it points out scientific evidence on such practice and future lines of research. In addition, more studies in primary education are needed. The sooner approaches that promote positive youth development are implemented, the better for prevention of relational and emotional difficulties.

It should be noted that research in the field is complex because WSRA may vary in their conceptual basis, principles, and methods according to their origins, and they may also have to adapt to a specific school's way of doing things, the cultural setting and related factors [10]. Specifically, the implementation of WSRA in schools involves careful awareness of the setting (e.g., clinical, state, private, etc.), participants (e.g., mixed ethnic groups, staff reticence, expectations of students, etc.), school culture (e.g., secular, religious, level of authoritarianism, etc.), and the history of the school community (e.g., school policy and commitment to move to a new educational approach, etc.) $[45,46]$. As for the setting, most of the studies were conducted in educational centers with a high degree of student diversity and situated in vulnerable areas at a social and economic level, which may make it difficult to generalize the results to other contexts. We suggest carrying out further studies in other settings to have more scientific data available to support the implementation of WSRA in broader international contexts. Further research should also consider the effect of context, type of school, and developmental stage on WSRA implementation. The sustainability of the WSRA implementation is relevant. It depends on the variability of financial support and the guarantee of stability in the training processes that support staff rotation. This makes study comparisons difficult, and in addition, each approach may have its own specificity. For instance, the Restorative Practices Intervention [6] and the Learning Together Intervention [34] may seem comparable but drilling down into the models shows they use different processes and practices. This should not be seen as a drawback but rather as the potential of WSRA to adapt to school reality by changing or creating processes to fit the setting. We propose the implementation of WSRA as a long-term and continuous process rather than a time-limited intervention [47]. Although most studies yielded significant results in the medium and long term, one should note that promising results were also shown in the very short term [38]. The implementation of the WSRA by means of educational psychology services might have generated a structure that optimized the processes required for proper WSRA implementation. More studies are needed to corroborate our hypothesis and, thus, be able to prepare more robust practice guidelines.

Although there are a few literature reviews on the implementation of restorative approaches in schools, none of them seem to focus specifically on the effects of WSRA. As already mentioned, they show some limitations $[14,22-26]$ that we address by means of a less-restricted literature search. Based on the scientific evidence available, the present work is a very first attempt to develop evidence-based practice guidelines on the effects of WSRA. To our knowledge, such an initiative has not been conducted to date. To do 
so, we used the SIGN system [29]. Compared to other systems used to evaluate evidence, this classification system assigns greater importance to the quality of the evidence behind each practice guidelines. It also highlights that the body of evidence should be regarded as a whole. It does not depend on single studies to support each practice guideline. It highlights the importance of well-conducted non-analytical studies to sustain practice guidelines when more rigorous designs such as randomized controlled trials cannot be carried out for practical or ethical reasons as it usually happens in the school setting [48]. A systematic review is considered the most appropriate methodology for evaluating the evidence available on a methodologically varied group of studies and procedures. Such diversity made it difficult to conduct a meta-analysis. Even when evaluating the same or similar WSRAs, there was a high level of diversity, and we were not able to combine the results into a general estimate of effect. Our study only included peer-reviewed studies. So, doctoral dissertations, master's theses, books or book chapters, meeting papers, and grey literature articles were out of our review, which may have decreased the body of evidence for our analyses and left aside important evaluation efforts [49]. It is worth noting that peer-review articles always underwent an evaluation process, which may, in turn, increase the level of evidence available for our analyses and resulting practice guidelines.

Our study offers evidence on the different approaches of WSRA used in schools and may generate leads about the links among WSRA and positive youth development, since as suggested by Acosta et al. (2021), restorative principles could be an effective means to boost positive youth development in school settings. That involves selecting an evidence-based approach that promotes positive youth development through supporting safe and protective school climates that may improve social, emotional, behavioral, and mental health outcomes for students. The research support for the implementation of WSRA approaches is encouraging especially for secondary education, adapting restorative principles to the heterogeneity of the cultural background in schooling context. They could be used to deal with diversity in terms of ethnicity and socio-economic adversity. The implementation of WSRA seems to generate a school culture of peace that promotes skills for the positive management of relationships and conflicts. Those skills are essential for daily-life functioning. Thus, their implementation may be promoting mental health and nurturing the resilience of the whole school community.

Author Contributions: Conceptualization, L.M.-E., V.K., J.A.A.-C., R.C., M.A. and L.L.-J.; methodology, L.M.-E., V.K., J.A.A.-C.; data curation, L.M.-E., V.K., J.A.A.-C.; writing-original draft preparation, L.M.-E., V.K., J.A.A.-C.; writing-review and editing L.M.-E., V.K., J.A.A.-C., R.C., M.A. and L.L.-J. All authors have read and agreed to the published version of the manuscript.

Funding: This study has been funded by Instituto de Salud Carlos III through the project "Evaluation of the effectiveness of the program for the education of social, emotional and mental health of adolescents living in residential care centers" with reference PI18/01859 (Co-funded by European Regional Development Fund/European Social Fund "A way to make Europe" / Investing in your future").

Institutional Review Board Statement: Not applicable.

Informed Consent Statement: Not applicable.

Data Availability Statement: Not applicable.

Conflicts of Interest: The authors declare no conflict of interest. The funders had no role in the design of the study; in the collection, analyses, or interpretation of data; in the writing of the manuscript, or in the decision to publish the results. 
Appendix A. The Main Characteristics of the Papers Identified

\begin{tabular}{|c|c|c|c|c|c|c|c|c|c|}
\hline $\begin{array}{l}\text { First Author } \\
\text { (Year) }\end{array}$ & Study Aim & Study Design & Sample and Setting & $\begin{array}{c}\text { Name of } \\
\text { Approach and } \\
\text { Duration of Implementation }\end{array}$ & Follow-Up & $\begin{array}{c}\text { Outcome } \\
\text { Measurement/ } \\
\text { Informants/Reliability }\end{array}$ & Data Analysis Method(s) & Significant Outcome & $\begin{array}{c}\text { Evidence } \\
\text { Level }\end{array}$ \\
\hline $\begin{array}{l}\text { Acosta } \\
(2019) \\
{[6]}\end{array}$ & $\begin{array}{l}\text { Evaluates the impact } \\
\text { of the restorative } \\
\text { practices intervention } \\
\text { to build a supportive } \\
\text { school environment }\end{array}$ & $\begin{array}{l}\text { Cluster randomized } \\
\text { controlled trial }\end{array}$ & $\begin{array}{c}n=2771 \text { students } \\
13 \text { middle schools } \\
\text { Age }=11-12 \text { years } \\
\text { Country (state /region): } \\
\text { USA (Maine) }\end{array}$ & $\begin{array}{l}\text { The Restorative Practice } \\
\text { Intervention } \\
2 \text { years }\end{array}$ & $\begin{array}{c}\text { Pre- and } \\
\text { post- } \\
\text { measures }\end{array}$ & 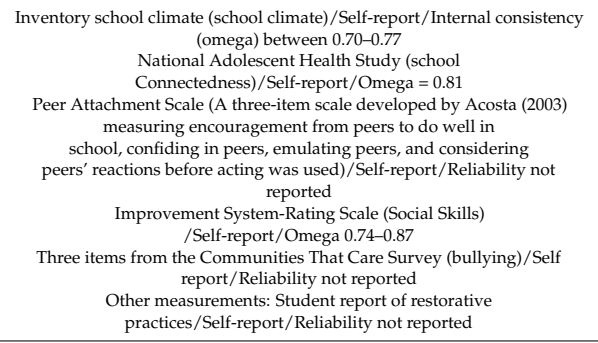 & $\begin{array}{l}\text { Exploratory and } \\
\text { confirmatory data analysis, } \\
\text { linear and logitsic } \\
\text { regression models }\end{array}$ & $\begin{array}{l}\text { No significicant differences between } \\
\text { intervention and control schools in student } \\
\text { outcomes (connectedness, developmental } \\
\text { outcomes, and bullying, victimization) }\end{array}$ & $1+$ \\
\hline $\begin{array}{c}\text { Bonell } \\
(2018) \\
{[34]}\end{array}$ & $\begin{array}{l}\text { Examines Learning } \\
\text { Together intervention } \\
\text { to modify shool } \\
\text { environment using } \\
\text { restorative practice } \\
\text { and by developing } \\
\text { social and emotional } \\
\text { skills in secondary } \\
\text { schoolers }\end{array}$ & $\begin{array}{l}\text { A Cluster randomized } \\
\text { trial }\end{array}$ & $\begin{array}{l}n=6667 \text { students ( } 83347 \\
\text { control group; } 3320 \\
\text { intervention group) } \\
40 \text { secondary schools } \\
\text { Age: 12-14 years } \\
\text { Country } \\
\text { (state/region): England } \\
\text { (greater London and } \\
\text { surroundings). }\end{array}$ & $\begin{array}{l}\text { Learning Together } \\
3 \text { years }\end{array}$ & 3 years & $\begin{array}{l}\text { Gatehouse Bullying Scale (bullying)/Self-report/Reliability not reported } \\
\text { Edinubroh Studd of Youth Transitions } \\
\text { and Crime (aggression)/Self-report/Reliability not reported }\end{array}$ & $\begin{array}{l}\text { Intraclass } \\
\text { correlation ceefficient } \\
\text { Repeated measures } \\
\text { analysis } \\
\text { Mixed linear regression } \\
\text { models with random effects }\end{array}$ & $\begin{array}{l}\text { Intervention had a small but significant effect } \\
\text { on bullying but no effect on aggression at } 24 \\
\text { months' follow-up. At } 36 \text { month's' follow-up, } \\
\text { the intervention group showed higher quality } \\
\text { of life and psychological well-being and } \\
\text { lower psychological difficultieis than the } \\
\text { control group. Intervention was associated } \\
\text { with reductions in police contact, smoking } \\
\text { and alcohol and drug use. }\end{array}$ & $1++$ \\
\hline $\begin{array}{l}\text { Goldys } \\
(2016) \\
{[32]}\end{array}$ & $\begin{array}{l}\text { Describes and } \\
\text { examines the } \\
\text { effectiveness of } \\
\text { restorative practices to } \\
\text { behavior change and } \\
\text { management, and the } \\
\text { promotion of a school } \\
\text { culture of peace } \\
\end{array}$ & Report & $\begin{array}{l}n=\text { not reported (students, } \\
\text { teachers, parents) } \\
\text { Elementary school } \\
\text { Age: Notr reported } \\
\text { Country (state region): USA } \\
\text { (Baltimore) }\end{array}$ & $\begin{array}{l}\text { Institutionalization of } \\
\text { restorative practices as the } \\
\text { behavior plan to change } \\
\text { school culture } \\
4 \text { years }\end{array}$ & $\begin{array}{l}\text { Post- } \\
\text { intervention } \\
\text { measures } \\
\text { Four-year } \\
\text { research }\end{array}$ & $\begin{array}{c}\text { Record restorative circles } \\
\text { Teacher and class registration } \\
\text { Parent surveys } \\
\text { Virtual Assemblies } \\
\text { Reliability of the measures is not reported }\end{array}$ & Not stated & $\begin{array}{l}\text { Decrease in physical aggression (55\%); } \\
\text { decrease in office referrals (55\%); decrease in } \\
\text { time missed from } \\
\text { Instruction (49\%), and enduring peacefulness } \\
\text { and students reported feeling safe in } \\
\text { school }(99.7 \%) \text {. }\end{array}$ & 3 \\
\hline$\underset{[37]}{\text { Gregory (2015) }}$ & $\begin{array}{l}\text { Examines the } \\
\text { experience of students } \\
\text { in classsooms utilizing } \\
\text { restorative practices }\end{array}$ & Quasi-experimental & 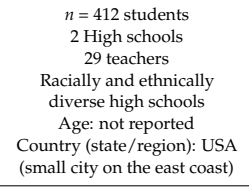 & $\begin{array}{l}\text { The Restorative Practice } \\
\text { Intervention } \\
1 \text { year }\end{array}$ & $\begin{array}{c}\text { Post- } \\
\text { intervention } \\
\text { measures }\end{array}$ & 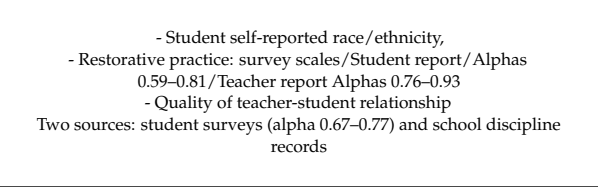 & $\begin{array}{l}\text { Hierarchical } \\
\text { linear modeling and } \\
\text { regression analyses }\end{array}$ & $\begin{array}{l}\text { Greater implementation levels associated } \\
\text { with better teacher-student relationships. } \\
\text { Students perceived teachers as morer } \\
\text { respectful, and they issued fewer discipline } \\
\text { referrals compared with low intervention } \\
\text { implementation. }\end{array}$ & $2+$ \\
\hline $\begin{array}{l}\text { Kehoe } \\
(2018) \\
440]\end{array}$ & $\begin{array}{l}\text { Explores the impact of } \\
\text { restorative practices } \\
\text { on student behavior }\end{array}$ & Qualitative study & $\begin{array}{l}n=54 \text { students } \\
\text { (14 teachers and } 40 \text { students) } \\
6 \text { primary and secondary } \\
\text { schols } \\
\text { Age: } 5 \text {-12 years (primary } \\
\text { schools and 12-18 years } \\
\text { (secondary schools } \\
\text { Country (tate/ /reion): } \\
\text { Australia } \\
\text { (Melbourine) }\end{array}$ & $\begin{array}{l}\text { H. E. A. R. T. } \\
\text { At least } 5 \text { years }\end{array}$ & $\begin{array}{c}\text { Post } \\
\text { measures }\end{array}$ & $\begin{array}{l}\text { Semi-structured interview and focus groups/Informants: teachers and } \\
\text { students/Reliability not reported }\end{array}$ & $\begin{array}{l}\text { Data analysis processes } \\
\text { with an inductive approach }\end{array}$ & $\begin{array}{l}\text { Better student behavior and social and } \\
\text { emotional skills. }\end{array}$ & 3 \\
\hline $\begin{array}{c}\text { Mansfield } \\
(2018) \\
{[13]}\end{array}$ & $\begin{array}{l}\text { Examines the impact } \\
\text { of restorative practices } \\
\text { on persistent } \\
\text { discipline gaps (race, } \\
\text { gender, and special } \\
\text { education) }\end{array}$ & Report & 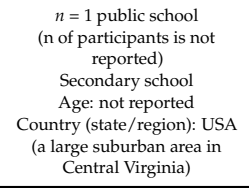 & $\begin{array}{l}\text { SafersanerSchools } \\
2 \text { years }\end{array}$ & $\begin{array}{c}\begin{array}{c}\text { Pre- and } \\
\text { post- } \\
\text { measures }\end{array} \\
\text {. }\end{array}$ & $\begin{array}{l}\text { Disciplinary data from } 2010 \text { to } 2015 \text {. Individual interviews with school and } \\
\text { district administrators/Reliability not reported }\end{array}$ & Not reported & $\begin{array}{l}\text { Decline in in-school and out-of-school } \\
\text { suspensions. The discipline gaps across } \\
\text { race ethricicity, gender and special education } \\
\text { decreased }\end{array}$ & $2-$ \\
\hline
\end{tabular}




\begin{tabular}{|c|c|c|c|c|c|c|c|c|c|}
\hline $\begin{array}{c}\text { First Author } \\
\text { (Year) }\end{array}$ & Study Aim & Study Design & Sample and Setting & $\begin{array}{c}\text { Name of } \\
\text { Approach and } \\
\text { Duration of Implementation }\end{array}$ & Follow-Up & $\begin{array}{c}\text { Outcome } \\
\text { Measurement/ } \\
\text { Informants/Reliability }\end{array}$ & Data Analysis Method(s) & Significant Outcome & $\begin{array}{l}\text { Evidence } \\
\text { Level }\end{array}$ \\
\hline $\begin{array}{c}\text { Mirsky } \\
(2007) \\
{[38]}\end{array}$ & $\begin{array}{l}\text { Describes the } \\
\text { implementation of } \\
\text { restorative practices at } \\
\text { three pilot schools }\end{array}$ & Report & $\begin{array}{c}n=3 \text { pilot school (2146 } \\
\text { students) } \\
1 \text { middde shool }(n=559) \text { and } \\
2 \text { high schools }(n=1587) \\
\text { Age: not reported } \\
\text { Country (state /region): USA } \\
\text { (southeastern Pennsylvania) }\end{array}$ & $\begin{array}{l}\text { SaferSanerSchools } \\
\text { From } 2 \text { to } 4 \text { years }\end{array}$ & $\begin{array}{c}\text { Pre-test-post- } \\
\text { test } \\
\text { measures }\end{array}$ & $\begin{array}{l}\text { Disciplinary data } \\
\text { Individual interviews/Reliability not reported }\end{array}$ & Not reported & $\begin{array}{l}\text { Decrease in: disciplinary referrals, detentions, } \\
\text { incidents of disturtive behavior and } \\
\text { out-of-school suspensions. }\end{array}$ & 3 \\
\hline $\begin{array}{l}\text { Moir } \\
(2018) \\
{[39]}\end{array}$ & $\begin{array}{l}\text { Examines the impact } \\
\text { the educational } \\
\text { psychology service } \\
\text { had on the } \\
\text { implementation of } \\
\text { restorative approach } \\
\text { activities across North } \\
\text { Ayrshire Council } \\
\text { schools }\end{array}$ & Quasi-experimental & $\begin{array}{c}n=95 \text { teachers representing: } \\
50 \text { primary schools, } 9 \\
\text { secondary schools, } 4 \text { special } \\
\text { cchools. } \\
18 \text { multi-agency partners } \\
\text { (health, police, social work } \\
\text { and other Educational } \\
\text { Psychology Services) } \\
\text { Aget not reported } \\
\text { Country (tsate/ region): } \\
\text { Scotland (North Ayrrshire } \\
\text { Council) }\end{array}$ & $\begin{array}{l}\text { Restorative Approaches of } \\
\text { Education Scotland } \\
6 \text { months }\end{array}$ & $\begin{array}{c}\text { Post- } \\
\text { intervention } \\
\text { measures }\end{array}$ & $\begin{array}{l}\text { Immediate Post-training self-report questionnaires, recall session } \\
\text { qualititative discussions, six-month post-staining feedback self-report } \\
\text { questionnaire and multiagency focus group. } \\
\text { Reliability of measureses not reporteded. }\end{array}$ & Data source triangulation & $\begin{array}{l}\text { Educational Psychology Services that } \\
\text { implemented Whhole School Restorative } \\
\text { Approaches, improved relationships and } \\
\text { reduced exclusions rreferrals to alternative } \\
\text { schools }\end{array}$ & 3 \\
\hline $\begin{array}{c}\text { Norris } \\
(2019) \\
{[12]}\end{array}$ & $\begin{array}{l}\text { Evaluates the impact } \\
\text { of restorative } \\
\text { approaches on } \\
\text { well-being (i.e., } \\
\text { happiness and school } \\
\text { engagement) across } \\
\text { three schools }\end{array}$ & Quasi-experimental & $\begin{array}{c}\text { Three schools: } \\
\text { School } 1(n=19), \\
\text { School } 2(n=289) \text { and School } \\
3(n=307) \\
\text { Age: years } 7,9 \text { and } 11 \text { of } \\
\text { secondary education. } \\
\text { Country (state/region): } \\
\text { United Kingdom } \\
\text { (not reported) }\end{array}$ & $\begin{array}{l}\text { School 1: Reactive-only } \\
\text { school approach. } \\
\text { School 2: Traditional whole } \\
\text { school approach. } \\
\text { School 3: Proaccative-only } \\
\text { whole school approach. } \\
18 \text { months }\end{array}$ & $\begin{array}{c}\text { Pre- and } \\
\text { post- } \\
\text { measures }\end{array}$ & $\begin{array}{l}\text { - Subjective Happiness Scale (Happiness) } \\
\text { - School Engagemenent Scale (School engagement) } \\
\text { Self-report measures. Reliability not reported. }\end{array}$ & $\begin{array}{l}2 \times 2 \text { between-subject } \\
\text { analysis of variance } \\
\text { (ANOVA) }\end{array}$ & $\begin{array}{l}\text { RA proactive-only whole-school approach } \\
\text { produced the most positive changeses in } \\
\text { happiness and school engagenent when } \\
\text { compared with the traditional whole school } \\
\text { approach }\end{array}$ & $2-$ \\
\hline $\begin{array}{l}\text { Shaw } \\
(2007) \\
{[41]}\end{array}$ & $\begin{array}{l}\text { Shows the findings of } \\
\text { a study implementing } \\
\text { a restorative practices } \\
\text { approach in } \\
\text { Australian schools and } \\
\text { consider how this } \\
\text { approach could } \\
\text { contribute to school } \\
\text { culture change }\end{array}$ & Qualitative study & $\begin{array}{c}n=18 \text { primary and } \\
\text { secondary school } \\
\text { Age: not reported } \\
\text { Country (state/region): } \\
\text { Australia } \\
\text { (Baltimore) }\end{array}$ & $\begin{array}{l}\text { Restorative practices } \\
\text { implementation within a } \\
\text { range encluding from } \\
\text { conferencing to a broader } \\
\text { framework of relationship } \\
\text { managagement and social skill } \\
\text { development } \\
2 \text { years }\end{array}$ & $\begin{array}{c}\text { Post- } \\
\text { intervention } \\
\text { measures }\end{array}$ & $\begin{array}{l}\text { Surveys and interviews. } \\
\text { Reliability not reported. }\end{array}$ & Not reported & 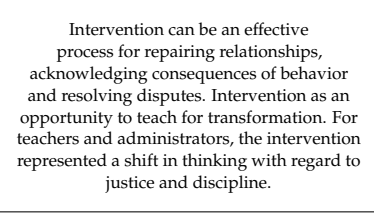 & 3 \\
\hline $\begin{array}{c}\text { Warren } \\
(2020) \\
{[35]}\end{array}$ & $\begin{array}{l}\text { Examines the } \\
\text { participants' accounts } \\
\text { of 'Learning Together' } \\
\text { whole-school } \\
\text { intervention-related } \\
\text { processes in the } \\
\text { prevention of bullying } \\
\text { and aggression as well } \\
\text { as the improvement in } \\
\text { student health in } \\
\text { England secondary } \\
\text { schools }\end{array}$ & $\begin{array}{l}\text { Qualitative study } \\
\text { within a randomized } \\
\text { controlled trial }\end{array}$ & $\begin{array}{c}n=3 \text { secondary schools } \\
\text { Students and statf } n \text { is not } \\
\text { stated) } \\
66 \text { interviews and focus } \\
\text { groups } \\
\text { Student age. } 11-14 \text { years } \\
\text { Country (state/ region): } \\
\text { England } \\
\text { (southeast) }\end{array}$ & $\begin{array}{l}\text { Learning Together } \\
3 \text { years }\end{array}$ & $\begin{array}{l}\text { Post- } \\
\text { intervention } \\
\text { measures at } \\
24 \text { and } \\
26 \text { months }\end{array}$ & $\begin{array}{l}\text { Interviews }(n=45 \text { ) and focus groups }(n=21) \\
\text { Reliability not reported. }\end{array}$ & Thematic content analysis & $\begin{array}{l}\text { Intervention helped to create a more inclusive } \\
\text { and cohesive school environments by means } \\
\text { of: (a) building student commitment to the } \\
\text { school community; (b) building healthy } \\
\text { relationships by modeling and } \\
\text { teaching pro-social skills, and (c) } \\
\text { de-escalating bullying and aggression and } \\
\text { enabling re-integration within the } \\
\text { school community. }\end{array}$ & 3 \\
\hline
\end{tabular}




\begin{tabular}{|c|c|c|c|c|c|c|c|c|c|}
\hline $\begin{array}{l}\text { First Author } \\
\text { (Year) }\end{array}$ & Study Aim & Study Design & Sample and Setting & $\begin{array}{c}\text { Name of } \\
\text { Apprach and } \\
\text { Duration of Implementation }\end{array}$ & Follow-Up & $\begin{array}{c}\text { Outcome } \\
\text { Measurement/ } \\
\text { Informants/Reliability }\end{array}$ & Data Analysis Method(s) & Significant Outcome & $\begin{array}{c}\text { Evidence } \\
\text { Level }\end{array}$ \\
\hline $\begin{array}{l}\text { Wong } \\
\text { (2011) } \\
{[36]}\end{array}$ & $\begin{array}{l}\text { Examines the } \\
\text { effectiveness of a } \\
\text { Restorative Whole- } \\
\text { School Approach to } \\
\text { reduce school bullying }\end{array}$ & Quasi-experimental & $\begin{array}{c}n=1176 \text { students } \\
n=4 \text { School } \\
\text { Secondary school } \\
\text { Aget 12-14years } \\
\text { Country (state/ eregion): } \\
\text { China } \\
\text { (Hong Kong) }\end{array}$ & $\begin{array}{l}\text { The Restorative } \\
\text { Whole-School Approach } \\
\text { 2 years }\end{array}$ & $\begin{array}{l}\text { Pre- and } \\
\text { post- } \\
\text { intervention } \\
\text { measures }\end{array}$ & 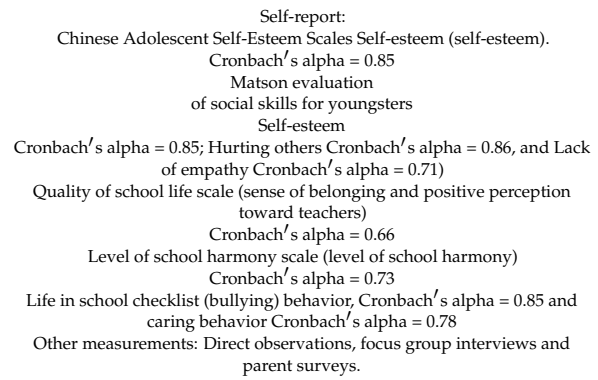 & $\begin{array}{l}\text { Within-subject comparison } \\
\text { analysis, paired } \\
t \text { test and treatment effect } \\
\text { size estimates }\end{array}$ & $\begin{array}{l}\text { The intervention group showed a significant } \\
\text { reduction in bullying, higher } \\
\text { empathic attitudes } \\
\text { and higher self-esteem in comparison to both } \\
\text { control groups }\end{array}$ & ${ }^{2++}$ \\
\hline
\end{tabular}




\section{References}

1. Cantor, P.; Osher, D.; Berg, J.; Steyer, L.; Rose, T. Malleability, plasticity, and individuality: How children learn and develop in context. Appl. Dev. Sci. 2019, 23, 307-337. [CrossRef]

2. Lerner, R.M.; Almerigi, J.B.; Theokas, C.; Lerner, J.V. Positive youth development a view of the issues. J. Early Adolesc. 2005, 25, 10-16. [CrossRef]

3. Larson, R.W. Toward a psychology of positive youth development. Am. Psychol. 2000, 55, 170-183. [CrossRef] [PubMed]

4. Lerner, J.V.; Phelps, E.; Forman, Y.; Bowers, E.P. Positive youth development. In Handbook of Adolescent Psychology: Individual Bases of Adolescent Development; Lerner, R.M., Steinberg, L., Eds.; John Wiley \& Sons, Inc.: New York, NY, USA, 2009; Volume 1, pp. 524-558.

5. Snyder, F.J.; Flay, B.R. Positive youth development. In The Handbook of Prosocial Education; Higgins-D'Alessandro, A., Corrigan, M., Brown, P., Eds.; Rowman and Littlefield Publishing Group: New York, NY, USA, 2012; Volume 1, pp. $415-443$.

6. Acosta, J.; Chinman, M.; Ebener, P.; Malone, P.S.; Phillips, A.; Wilks, A. Evaluation of a Whole-School Change Intervention: Findings from a Two-Year Cluster-Randomized Trial of the Restorative Practices Intervention. J. Youth Adolesc. 2019, 48, 876-890. [CrossRef]

7. Catalano, R.F.; Berglund, M.L.; Ryan, J.A.M.; Lonczak, H.S.; Hawkins, J.D. Positive youth development in the United States: Research findings on evaluations of positive youth development programs. Ann. Am. Acad. 2004, 591, 98-124. [CrossRef]

8. Acosta, J.D.; Chinman, M.; Phillips, A. Promoting positive youth development through healthy middle school environments. In Handbook of Positive Youth Development; Dimitrova, R., Wiium, N., Eds.; Springer: Berlin/Heidelberg, Germany, 2021; pp. 483-500.

9. Bevington, T.J. Appreciative evaluation of restorative approaches in schools. Pastor. Care Educ. 2015, 33, 105-115. [CrossRef]

10. McCluskey, G. Exclusion from school: What can "included" pupils tell us? Br. Educ. Res. J. 2008, 34, 447-466. [CrossRef]

11. Zehr, H. The Little Book of Restorative Justice. In A Bestselling Book by One of the Founders of the Movement; Good Books: Intercourse, PA, USA, 2002.

12. Norris, H. The impact of restorative approaches on well-being: An evaluation of happiness and engagement in schools. Confl. Resolut. Q. 2019, 36, 221-234. [CrossRef]

13. Mansfield, K.C.; Fowler, B.; Rainbolt, S. The Potential of Restorative Practices to Ameliorate Discipline Gaps: The Story of One High School's Leadership Team. Educ. Adm. Q. 2018, 54, 303-323. [CrossRef]

14. Mayworm, A.M.; Sharkey, J.D.; Hunnicutt, K.L.; Schiedel, K.C. Teacher Consultation to Enhance Implementation of School-Based Restorative Justice. J. Educ. Psychol. Consult. 2016, 26, 385-412. [CrossRef]

15. González, T.; Sattler, H.; Buth, A.J. New directions in whole-school restorative justice implementation. Confl. Resolut. Q. 2019, 36, 207-220. [CrossRef]

16. Reimer, K.E. Relationships of control and relationships of engagement: How educator intentions intersect with student experiences of restorative justice. J. Peace Educ. 2019, 16, 49-77. [CrossRef]

17. McCluskey, G. Restorative Approaches in Schools: Current Practices, Future Directions. In The Palgrave International Handbook of School Discipline, Surveillance, and Social Control; Deakin, J., Taylor, E., Kupchik, A., Eds.; Palgrave Macmillan: Cham, UK, 2018.

18. Wadhwa, A. Restorative Justice in Urban Schools: Disrupting the School-To-Prison PipelineK, 1st ed.; Routledge Research in Educational Leadership: New York, NY, USA, 2016.

19. Hendry, R. Building and Restoring Respectful Relationships in Schools: A Guide to Using Restorative Practice, 1st ed.; Routledge: London, UK, 2009.

20. Lerner, R.M.; Lerner, J.V.; Benson, J.B. Positive youth development: Research and applications for promoting thriving in adolescence. Adv. Child Dev. Behav. 2011, 41, 1-17. [CrossRef] [PubMed]

21. Frias-Armentia, M.; Rodríguez-Macías, J.C.; Corral-Verdugo, V.; Caso-Niebla, J.; García-Arizmendi, V. Restorative justice: A model of school violence prevention. Sci. J. Educ. 2018, 6, 39-45. [CrossRef]

22. Kline, D. Can Restorative Practices Help to Reduce Disparities in School Discipline Data? A Review of the Literature. Multicult. Perspect. 2016, 18, 97-102. [CrossRef]

23. Fronius, T.; Darling-Hammond, S.; Persson, H.; Guckenburg, S.; Hurley, N.; Petrosino, A. Restorative Justice in U.S. Schools. An Updated Research Review; WestEd Justice \& Prevention Research Center; WestEd: San Francisco, CA, USA, 2019. Available online: https:/ / www.wested.org/wp-content/uploads/2019/04/resource-restorative-justice-in-u-s-schools-an-updatedresearch-review.pdf (accessed on 20 November 2021).

24. Anfara, V.; Evans, K.; Lester, J. Restorative Justice in Education: What We Know so Far. Middle Sch. J. 2013, 44, 57-63. [CrossRef]

25. Weber, C.; Vereenooghe, L. Reducing conflicts in school environments using restorative practices: A systematic review. Int. J. Educ. Res. 2020, 1, 1009. [CrossRef]

26. Katic, B.; Alba, L.A.; Johnson, A.H. A Systematic Evaluation of Restorative Justice Practices: School Violence Prevention and Response. J. Sch. Violence 2020, 19, 579-593. [CrossRef]

27. Page, M.J.; Moher, D.; Bossuyt, P.M.; Boutron, I.; Hoffmann, T.C.; Mulrow, C.D.; Shamseer, L.; Tetzlaff, J.M.; Akl, E.A.; Brennan, S.E.; et al. PRISMA 2020 explanation and elaboration: Updated guidance and exemplars for reporting systematic reviews. BMJ 2021, 372, 160. [CrossRef]

28. Hall, T. Review of Experimental Social Behavioral Interventions for Preschool Children: An Evidenced-Based Synthesis. SAGE Open 2020, 10, 1-13. [CrossRef] 
29. Scottish Intercollegiate Guidelines Network. SIGN 50: A Guideline Developer's Handbook; Scottish Intercollegiate Guidelines Network: Edinburgh, UK, 2011.

30. Kazdin, A.E. Single-Case Research Designs: Methods for Clinical and Applied Settings, 2nd ed.; Oxford University Press: Oxford, UK, 2011.

31. Cohen, J. Some statistical issues in psychological research. In Handbook of Clinical Psychology; Wolman, B.B., Ed.; McGraw-Hill: New York, NY, USA, 1965; pp. 95-121.

32. Goldys, P. Restorative practices: From candy and punishment to celebration and problem-solving circles. J. Character Educ. 2016, $12,75-80$

33. Reimer, K.E. An exploration of the implementation of restorative justice in an Ontario public school. Can. J. Educ. Adm. 2011, $119,1-42$.

34. Bonell, C.; Allen, E.; Warren, E.; McGowan, J.; Bevilacqua, L.; Jamal, F.; Viner, R.M. Effects of the Learning Together intervention on bullying and aggression in English secondary schools (INCLUSIVE): A cluster randomised controlled trial. Lancet 2018, 8, 2452-2464. [CrossRef]

35. Warren, E.; Melendez-Torres, G.J.; Viner, R.; Bonell, C. Using qualitative research to explore intervention mechanisms: Findings from the trial of the Learning Together whole-school health intervention. Trials 2020, 21, 774. [CrossRef]

36. Wong, D.S.; Cheng, C.H.; Ngan, R.M.; Ma, S.K. Program effectiveness of a Restorative Whole-school Approach for tackling school bullying in Hong Kong. Int. J. Offender Ther. Comp. 2011, 55, 846-862. [CrossRef]

37. Gregory, A.; Clawson, K.; Davis, A.; Gerewitz, J. The Promise of Restorative Practices to Transform Teacher-Student Relationships and Achieve Equity in School Discipline. J. Educ. Psychol. Consult. 2015, 26, 1-29. [CrossRef]

38. Mirsky, L. SaferSanerSchools: Transforming School Cultures with Restorative Practices. Reclaiming Children and Youth. J. Strength-Based Interv. 2007, 16, 5-12.

39. Moir, T.; MacLeod, S. What impact has the Educational Psychology Service had on the implementation of restorative approaches activities within schools across a Scottish Local Authority? Educ. Child Psychol. 2018, 35, 30-42.

40. Kehoe, M.; Bourke-Taylor, H.; Broderick, D. Developing student social skills using restorative practices: A new framework called H.E.A.R.T. Soc. Psychol. Educ. 2018, 21, 189-207. [CrossRef]

41. Shaw, G. Restorative Practices in Australian Schools: Changing Relationships, Changing Culture. Confl. Resolut. Q. 2007, 25, 127-135. [CrossRef]

42. Silverman, J.; Mee, M. Using Restorative Practices to Prepare Teachers to Meet the Needs of Young Adolescents. Educ. Sci. 2018, 8, 131. [CrossRef]

43. Lawlor, J.; Mills, K.; Neal, Z.; Neal, J.N.; Wilson, C.; McAlindon, K. Approaches to measuring use of research evidence in K-12 settings: A systematic review. Educ. Res. Rev. 2019, 27, 218-228. [CrossRef] [PubMed]

44. Morgan, H. Restorative Justice and the School-to-Prison Pipeline: A Review of Existing Literature. Educ. Sci. 2021, 11, 159. [CrossRef]

45. Power, S.A.; Velez, G.; Qadafi, A.; Tennant, J. The SAGE Model of Social Psychological Research. Perspect. Psychol. Sci. 2018, 13, 359-372. [CrossRef] [PubMed]

46. Power, S.A.; Velez, G. The MOVE Framework: Meanings, Observations, Viewpoints, and Experiences in processes of Social Change. Rev. Gen. Psychol. 2020, 24, 321-334. [CrossRef]

47. White, A. Transformative School-Community-Based Restorative Justice: An Inquiry into Practitioners' Experiences. Ph.D. Thesis, Loyola Marymount University, Los Angeles, CA, USA, 2019.

48. Manterola, C.; Asenjo-Lobos, C.; Otzen, T. Hierarchy of evidence. Levels of evidence and grades of recommendation from current use. Rev. Chilena Infectol. 2014, 31, 705-718. [CrossRef]

49. Augustine, C.H.; Engberg, J.; Grimm, G.E.; Lee, E.; Wang, E.L.; Christianson, K.; Jospeh, A.A. Can Restorative Practices Improve School Climate and Curb Suspensions? An Evaluation of the Impact of Restorative Practices in a Mid-Sized Urban School District; RAND Corporation: Santa Monica, CA, USA. Available online: https:/ / www.rand.org/pubs/research_reports/RR2840.html (accessed on 28 February 2022). 